\title{
Universal Vision in the Fiction of Ben Okri
}

\section{Srividya Nammi}

Research Scholar

India

srividya.nammi@gmail.com

\section{Abstract}

Okri's fiction is a mix of fantasy, realism and oral tradition of Africa. Though the trilogy nearly covers some fourteen hundred odd pages, it doesn't have a proper beginning or end. Okri's view of an unnamedAfrican ghetto, which is going to get independence, is presented in these novels. He is not giving solutions to the existing problems, he is simply presenting the true nature of an African state in an elusive manner. He narrates The Famished Road through the experiences of an 'abiku', Azaro, a seven year old child. He uses Azaro to narrate the chaotic state of affairs in an African state, and educates Azaro with the rich African culture in the form of stories told by his mother and father, and shows the real state of Africa in the form of photographs taken by the photographer, Jeremiah. Okri's fiction has many layers of meaning which makes the task of analysis difficult. Though several labels like magical realism, Post-colonial, post-modern text are given the trilogy defies any particular definition. After examining his Trilogy thoroughly, it seems that Okri though elusive in his writings apparently wants a new - world. The Trilogy moves in the direction of anticipating a world fine tuned to harmonious living.

The main characters Azaro, Dad, Madame Koto, the photographer and mum are chosen to present the corrupt Africa and the consequences it will be facing in the immediate future. He is not showing colonialism as the cause for the present state 
of affairs, at the same time he is not showing one particular reason for the present chaotic state. Okri's universal vision can be seen if we observe the long philosophical lectures of Dad and examine the other characters carefully. In an early review of the book, Kwame Anthony Appiah emphasizes The Famished Road's "spiritual" terms of reference, and he distinguishes Okri's "spiritual realism" from the more postmodern and postcolonial "magical realism" of Latin American authors. He says that there is a difference between theways in which Latin American writers draw on the supernatural and the way that Okri does. Appiah goes on to note that Okri's own spiritual views are oftentoo transparently communicated, modulating the novel's exuberant "spiritual realism into an irritatingly pseudomystical NewAge mode" of discourse. For Okri, in a curious way , the world of spirits is not metaphorical or imaginary ; rather, it is more real than the world of the everyday (148).Okri uses fetishes, masks, and "aquamarine beginnings" to show that physical and spiritual worlds co-exist. In the Trilogy Okri explores African society through the wanderings, dreams, experiences and nightmares of his young protagonist, Azaro. Africans believe in spirit children, and they call such children as 'abikus'. These 'abikus' torment their mothers by their repeated births and deaths. 'Abikus' are spirits in the guise of babies who are born repeatedly only to die and return to the spirit world. Azaro is vulnerable to the call and threat of his spirit companions. "His world is the bizarre product of both new and old, tradition and burgeoning change. Azaro observes the hybrid cacophony and synchronizing, creating something new" (Cooper, Snapshots 145).

Okri synchronizes old andnew cultures; this synchronization can be seen in Azaro's description of Madame Koto's party. As night approaches, the rowdiness of the guests mysteriously diminishes. Only the drunken musicians keep up their performances. Sitting at different tables, they play their conflicting music, competing with one another, answering dirges with praise - songs, assaulting the epic harmonywith the withering satires, 
undermining the mnemonic feats of dynastic musicians with songs of lust competing with songs of work. Their different kinds of music fight one another in their hidden ideologies and world views. They warred with music, carrying on where the main guests have left off. The musicians suddenly stop as if the wind and night are canceling out their music. Azaro learns that a yellow bird flew across Madame Koto's head and shat on her crown of rock-beads. One of the guests from Bamako considers it as a bad omen. By this Okri shows that though people enjoy and learn music which is a symbol of western civilization yet the same time they still believe in omens and signs.

Masquerades and spirits are used exclusively throughout the trilogy to emphasize the importance of spirits in revitalizing human life in the physical world. Azaro observes long legged spiders while listening to his father's words. When he turns his head he sees nothing. But they keep moving closer, like crabs or a phalanx of Roman soldiers, changing positions with the movement of his head. The mosquitoes flitted round him. A lizard scuttled across his father's hat. The mosquitoes flew into his ears and whine in his brain. The driver stops snoring. The masquerade's kingdom began to invade his mind. He feels its gigantic presence in him, alien and dark, like the shadow of a compacted mountain in a small room. Azaro feels the spaces in him crowded out, stretched and bursting with this unholy occupation. The essences of the unborn, the lust of life, and the darkness of death compress themselves into Azaro. And for the first time Azaro becomes aware that just as he could unintentionally enter the spirit of things, they too could enter into him. And the masquerade, howling in his mind, watches Azaro's father through his eyes. According to Hemminger the Trilogy can be treated as a record of powerful, dangerous and beneficial aspects of the spirit world as it relates to the physical world.

In songs of enchantment, Azaro echoes his father's earlier comment that everything is alive. Indeed the world is inhabited not only by humans and spirits but also by ambulatory 
trees, liquid roads, masquerades that pitch and fight. In Azaro's world future events present themselves in phantasms and portents alongside relived histories and current - day injustices. Azaro and many other characters in the Trilogy seem to accept the presence of all other beings and things. By this "Okri seems to suggest that humans need to take their places alongside other things in the world, that humans have little if any control over those things, and that a mature and responsible human accepts the presence and inherent value of all other things" (Hemminger 73).Okri mixes myth and social realism, because he doesn't wish to reduce the complexity of Africa into socio-political problems. Africa is continuously troubled by the socio-political structure of the nation. Okri's trilogy is not only concerned about myth and social realism but also asserts that "every thing is alive". Okri uses the character of Azaro's father as his mouth piece and shows the significance of all beings. Azaro's father respects all creatures, even rats that co-exist with their family. He asks Azaro to listen to rats. "Azaro, rats can be our friends. They can sometimes tell what is happening in the world. They are our spies" (FR 84). Azaro understands the language of rats and he hears them saying "that the world is tougher than fire or steel" (ㅌR 85). "Azaro is in some ways 'formed' by his dad's accomplishments. What the child 'understands' surely exceeds the limits of his cognitive powers; he learns about life from his father"(Hemminger 79). For Azaro the world is alive in many ways, the market place, for instance, is much more than the coming together of hawkers and buyers in the crowded clearing of an African city.Azaro describes people, walking, Stray dogs prowling chickens flapping in cages, goats gazing with lidless eyes-and also his feeling of hurt looking at them. When he closes his eyes and opens them Azaro's empathy with all living creatures is the point to be registered.The ominous visions of people walking backwards, a dwarf with two fingers, men upside- down with baskets of fish on their feet, women who had breasts on their backs, babies strapped to their chests and beautiful 
children with three arms, a girl amongst them who had eyes at the side of her face, indicate the abnormal, distorted nature of life in contemporary thought.

Azaro in one of his wanderings goes deep into the forest, when he notices that many trees had been fallen to build companies. He observes a felled tree from the stump of which red liquid drips. Okri intends to show the importance of Ecology in man's life. It is not difficult to imagine what trees might say in the assault-especially in a world where, as many characters in the novel assert, "everything is alive" (SE 222). Man's happiness is interdependent, all other things play a vital role in bringing harmony to man. Azaro's father recognizes "the interdependence of all living elements of the world" and tells his son that they have to treat all other creatures with respect.

Humans become stewards of the world, caretakers in the most significant sense of the entire world, including themselves. These thoughts can be seen in the following statements of Azaro's father:

Listen to the spirit of things. To your own spirit $[\ldots]$ so long as we are alive, so long as we feel, so long as we love, everything in us is an energy we can use $[\ldots]$ all creatures must be treated with respect from now on $[\ldots]$ we must not become tyrants, you hear? (FR499)

Azaro is troubled by visions and spirits. He travels between the physical and the spirit worlds. Azaro is torn between physical and spirit-worlds. Though he opts for continued existence as part of the ghetto community, he is still visited by visions and haunted by spirits both benign and malevolent. "Azaro is a protagonist who "materialized in some under water kingdom" only to flit between physical and spiritual worlds throughout his childhood of 
course, Azaro's case is an exceptional one, yet Okri suggests that all people, as discussed earlier are similarly constituted" (Hemminger 73 -74).

In the trilogy the spirits are everywhere. They are eager to taste human things, Azaro watches them as they laugh and bang the tables. Then he realizes for the first time that many customers are not human beings. Their expressions and moments are at odds with their bodies. They look like a confused assortment of different human parts. It occurs to Azaro that they were spirits who had borrowed bits of human beings to partake of human reality. "In turn, the spirits revitalize human life, rein spire a world grown compartmental and cold" (Hemminger 74).Their deformations are too staggering and they seem unaffected by their deformities. Africans believe that self is a composite of different elements. The combination of social reality with fantasy turns the Trilogy into a mix of compound structure. Thus Azaro's subjectivity corresponds with African ontology which defines the self as a composite of different elements:

Each of the identifiable life forces of the universe-from the gain of sand to the ancestor-is, itself and in its turn, a network of life forces-as modern physical chemistry confirms: a network of elements that are contradictory in appearance but really complementary. Thus, for the African,man is composed of course of matter and spirit, body and soul, but at the same time he is all composed of a virile and a feminine element: indeed of several "souls", man [sic] is therefore a composition of mobile life forces which interlock; a world of solidarities that seek to knit themselves together. (Leopold 31)

Azaro in one of his visions sees the destruction of trees and feels that in the new age their living space or thinking reduced due to human failure to understand other creatures. Azaro witnesses the destruction in his vision. He witnesses the destruction of great shrines, death of mighty trees which stored soothing memories. He even speaks about the death of 
their many roads, ways and philosophies. He visualizes the trees retreat screaming into the blue earth and hears the conversation of great spirits of the land and forest talking of a temporary exile. Okri in his Trilogy tries to make the readers realize that man is responsible for the destruction of environment. Due to man's materialistic rush his relationship with nature is altered. This is revealed in the following words of Azaro. "As the freedom of space and friendship with the pied kingfisher and other birds became more limited with the new age, something died in me" (FR 524).Okri is preaching that man has to protect nature to have harmony in the world.

Azaro's father too tells a similar story, he tells Azaro about a dream in which he talks with trees and later they disappear and a man with no eyes tells him that people like him destroyed them. Okri is showing that man is responsible for the destruction of ecology.

The trees could talk and they tell him their life stories. Then people appeared and began to cut down the trees. The rainbows started to fade. The world became darker. [...] All the rainbows had gone. All the beautiful colors of the world had gone. The trees were turning into stumps. Some of them were bleeding, many of them were ghosts.[...]People like you have been destroying them.(SE 266)

Azaro and his father depict suffering and ecological destruction throughout the Trilogy. According to Vazquez, Azaro grows from childhood to adulthood by developing a greater social awareness, in "The Famished Road the sympathy that the protagonist feels towards the community increases progressively throughout the narrative"(Vazquez 93). Azaro sees his parent's pathetic working conditions and equates their pain with the pain of all other men and women. Azaro feels painful when he observes people staggering under the weight of salt bags, cement bags, and garri sacks in the garage where his father worked. When he goes to the market in search of his mother there he observes that her tiredness and sacrifice were not hers alone but were suffered by all women of the market place. 
Lives of people in the Trilogy are plagued by politics and corruption. Loose episodes about politics reveal the "political disintegration" and the "universal human cycle of greed “(Cooper, Magical Realism 90). Okri in his Trilogy throws light on the political distress prevailing in Africa .Okri's Trilogy shows that the present political situation is responsible for the corruption that is prevailing in the society. There is not much between the twopolitical parties: The party of the 'Rich' and the party of the 'Poor'. Both the parties compete with each other, in making promises to lure people for votes. Both the parties are not interested in doing any good to people. They compete with each other using loud hailers,leaflets and empty promises. There is, however, not much to choose between them. "Okri continues to be elusive about the significance, desirability, or even the reality of change. He expresses unrelieved cynicism for the vices of the political parties"(Cooper,Magical Realism 86). Okri vividly portrays the nature of modern Nigerian politics in the following passage:

It became quite confusing to hear both parties virtually promise the same things. The party of the rich talked of prosperity for all, good roads, electricity, and free education. They called the opposition thieves, tribalists, and bandits. At their rally, they said, everyone would be fed, all questions would be answered . That evening the van of the party for the poor also paraded our street. They too blared music and made identical claims. They distributed leaflets and made their promises in four languages. when the two vans, each packed with armed bodyguards, passed one another, they competed with the amount of noise they could generate ....The two vans clashed twice that evening. we kept expecting some sort of war to break out, but both parties seemed restrained by the healthy respect they had developed for one another.(FR 390) 
The legacy of colonialism is only mentioned, but it is not shown responsible for the present state of political milieu . Okri doesn't blame the colonial order directly, but he gives some details about the colonial impact in his Infinite Riches:

There's been too much attribution of power to the effect of Colonialism on our consciousness. Too much has been given to it. We've looked too much in that direction and have forgotten about our own aesthetic frames. Even though that was there and took place and invaded the social structure, it's quite possible that it didn't invade our spiritual and aesthetic and mythic internal structures, the way in which we perceive the world. Because if one were going to be investigative, one would probably say that a true invasion takes place not when a society has been taken over by another society in terms of its infrastructure, but in terms of its dreams and myths, and its perception of reality. If the perception of reality has not been fundamentally, internally altered, then the experience itself is just transitional. There are certain areas of the African consciousness which will remain inviolate. Because the world-view, it is that makes a people survive. (Qtd. in interview with Ben Okri 86)

Azaro mentions about a sergeant-major who becomes anxious when the group of women along with Azaro's mother go to the police station. "The sergeant -major panicked and blew his whistle, thinking that colonial order was being overthrown, or that a new war of liberation had been launched" (IR 22).

The governor general looks at the people of Africa only "as shapes with menacing eyes and too many languages,too many leaders"(IR 38).He burns all the crucial papers relating to the governance of the country. After burning all the documents relating to the nation he starts rewriting their history. With the arrival of White men he begins Africa's history. The governor general deprives them of civilization and "unintentionally, deprives 
them of humanity too" (IR 126).While writing African history the Governor-General renames their meadows and valleys - and forgets their slave trade. He rewrites the beauty and meaning of their customs, he abolishes the world of spirits, diminishes their feats of memory, turns their philosophies into crude superstitions, their rituals into childish dances, their religions into crude relics and primitive forms, their drums into instruments of jest their music into simplistic babbling. The governor-general writes their history without observing the true nature of the place. The White man had never observed how Africans lived. In the end the white man realizes"that though he had been in the continent for fifteen years he didn't have the slightest idea of the true nature of the place" (IR 181).

The governor-general is disturbed by the yellow moth of Africa and due to its influence, in his writings, he praises African's polygamous thinking and polygamous gods. He notes that "instinct is the genius in paradise" (IR 187).He feels like an African himself. He questions the fate of imperialists -"the inevitable dissolution of overreaches. He feels their power over the world will vanish like the power of Romans. This shows how a white ruler has been over whelmed by African culture.

A deformed woman is not accepted by the society, so she starts living in the forest, and cares the wounded beasts and strange children. She goes away from the wickedness and hypocrisy of human beings. She watches the changes in society from her hut in the forest. She weaves long cloth of stories consisting people's secret narratives. The old woman and the governor general, in their writings show that all humans are equal and their writings echo collectiveness of people around the world. The following passage shows that universal love will beget majestic power:

She even coded fragments of the great jig saw that the creator spread all over the diverse peoples of the earth, hinting that no one race or people can 
have the complete picture or monopoly of the ultimate possibilities of the human genius alone (IR 128).

Okri stresses that god has distributed divinity and human genius to all the people in the universe in different ratios and no one can have the complete picture alone. Okri expresses this through the writings of the governor general. Okri in his fiction reveals that people can have this picture of divinity or humanity only when different people of the earth meet and learn to love one another. The governor general even writes that no one person or race can have the possession of this jigsaw of humanity.He even suggests that people can make use of this universal gift only when they come together as one people and face their common predicament and common love.

Azaro's friend too talks to Azaro about the new age, whichis going to come. He tells him that in the new age there will be many changes and the world will be filled with soldiers, ugliness and blindness. Great transformation will take place in the world when people least expect it. People who suffer will know justice and beauty. People will realize the meaning of hope and struggle due to the wonderful change. Then people will be peaceful and after some time they will forget the meaning of struggle and hope and things will again become worse. This process of becoming good and bad will repeat continuously like the spirit child who keeps coming and going. Hence Ade compares their country to an 'abiku' child but in the end he reveals that one day it will decide to remain. So Okri's trilogy wishes to find peace and harmony in the new age.

Azaro's father too keeps on talking about "new age." Azaro's father explains a mystical revolutionary dream vision to his family, proclaiming that a 'new age' is coming in which the vast spiritual potential of human beings and their interconnectedness with the universe will be revealed. Azaro's father mentions that in the 'new age' man is enlightened so he can't be defeated or kept down. Okri through the character of Azaro's father shows that 
man can re dream the world and make the dream real. He shows that human beings are gods hidden from them. People are not afraid of death they are afraid of love. Human history which is an undiscovered continent contains many things and they are all preserved in the heart of man which is bigger than a man. Okri is portraying that man is engulfed by many things. McCabe confirms the same notion in the following passage:

Dad's revelation contains every item on the New age shopping list; it promulgates spiritual evolutionism ("we are entering a new age"; loving monism :we should not be afraid of "love" because we are inter connected to all things; " the sky is inside us" ) ; co-creative idealism ("we can re-dream the world and make the real") ;self actualization("human beings are gods hidden from themselves"); and, finally, the sense that an individual's inner voice can help him rise above the sclerosis of institutionalized traditions and material conditions of existence. (McCabe 12)

To some extent the 'abiku' may reside in every one. That is man's mind will be continuously thinking about something or the other. Each individual will be thinking differently. Man is a social animal and society is a mix of many things. The circumstances and people that surround a man will have their impact on man's thinking. In the trilogy Okri uses 'abiku' child Azaro to portray different aspects which are affecting man's life. Azaro keeps moving between the real world and the spirit world. Similarly the other characters also speak about their dreams and imaginations which are connected to the real world as well as to the other world. This tendency can be seen in all individuals:

We are all "abikus", says Okri in an interview- meaning not that we are all decentred, labile subjects of the kind celebrated by post modernity, but rather subjects alienated, like abiku, from their true home, possessing rich spiritual depths that can be more or less realized in the terrestrial plane of existence to which they have been exiled. For Okri, to be an abiku- to apprehend the paradox, mystery and 
fleeting beauty that glimpses of the spirit- world bring- is to put oneself and the society one inhabits on the road to heaven. (McCabe 16)

Other central motive which supports the trilogy's 'New' age is hunger. In $\underline{T h e}$

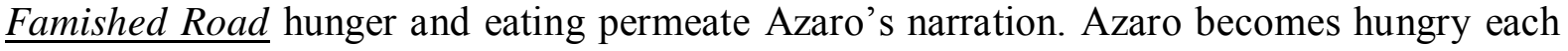
time in his wanderings and numerous journeys. Azaro's as well as other characters hunger is also a spiritual hunger. Whereas Azaro's father's hunger is a positive one as he proclaims that "God is hungry for us to grow" and that hunger can change the world, make it better, sweeter. Azaro's hunger which is not different from his father' leads him into the ecstasy of everlasting love.

Okri hints that social realism in itself is not adequate enough to portray the actuality of the African land. He uses the character of the photographer to convey this message. The photographer stands for the artist in general. "The photographer tries to capture what he seesthat is, the external dimension of the objects- by means of a naturalistic technique"(Vazquez 89). The photographer captures portraits of families as well as the political scandals and corruption of the new state about to emerge. "Okri documents a political agenda of national healing" (Cooper, snapshots 146). The photographer is tortured by political thugs for revealing their true nature, he becomes a mythical hero.

The photographer is a representative of the modern man seeking his own freedom and a global understanding. He returns from having been "round the world and back" (ㅌR 260) and "seen wonders as well as terrible things"(FR 280). The photographer challenges tradition, by undertaking several travels throughout the trilogy. He is in favor of fearless wanderlust and curiosity about the world. He tells Azaro that he will travel all the roads of the world and take photographs of the things which attract his attention.

At the same time, Okri resolutely refuses to reinforce the most obvious polarities such as that between technological progresses in opposition to the past. For example, the forest 
rebels against its violation by so-called progress. In a huge storm that signifies the end of the harmattan and the beginning of the rainy season 'the freshly laid tarmac had been swept away : and all those who were building the road intended to connect the high way had flood for cover and were nowhere to be seen" (FR287).

The white over seer and the workers who foolishly try to save him are swept away in a stream of flood waters ominously described as originating from the forest. The colonial road is reduced to "what it used to be, a stream of primeval mud, a river"(FR 286). The storm however is linked to the new technology with the image of God as "the great photographer" with the lightening flash bulbs."The polarities are repeatedly contested even as they are established. The organic natural world of the pre-colonial past is not allowed to be pitted against the technological scientific innovations of the white engineer and the society he represents" (Cooper, Magical Realism 80).

The photographer tries to capture social reality and he represents Okri's realistic narrative, Where as Madame Koto and the blind old man with their corrupt means represent protruding power structures. Throughout the trilogy Okri shows conflicting forces.Azaro is troubled by his spirit companions, and is forever in confrontation with the spirit world and the real world. Madame Koto, the bar owner tries to conquer the energies of people, the ghetto is troubled by political parties, thugs, natural calamities and to a greater extent the riches of Madame Koto. Okri juxtaposes fabulous wealth besides utter poverty. People suffer due to it without their knowledge and its affect is seen in the spoilt parties of Madame Koto.

Okri’s Trilogy defies classification. Okri himself asserts that the African artist must combine realistic and non realistic images if he is to portray the true nature of the continent. Okri forges a hybrid narrative, which has been described as an example of "magical realism" or "spiritual realism".Stories have always been at the heart of his writing. The Famished $\underline{\text { Road }}$ is nearly encyclopedic collection of tales about its boy- hero, Azaro, as he moves easily 
between the world of the flesh and the world of spirits.This generous story telling comes naturally to Okri. Azaro swings between two extreme worlds, Madame Koto and the blind old man too can cross the extreme world like Azaro, but in a negative way.

Okri's trilogy shows universality as its main theme. There is no ambiguity in this; his work belongs to New Age spiritual discourse in general and his views on politics and spirituality in particular. Okri does not talk about Africa alone; he is talking about all countries, in fact about universe. His trilogy is a mix of suffering, pain, chaos, natural calamities, political violence, corruption, family ties, myth and fantasy. The whole theme of the trilogy is man has forgotten to 'love' the things created by god due to his selfishness and this resulted in his suffering. Okri repeatedly stresses that man has to learn to 'love' to achieve harmony and peace in the world which is cut into innumerable ribbon pieces. Violence, corruption, politics are common to Africa. Their history revolves around these issues. People in Africa are superstitious and they perform many customs, to please their Gods and ancestors and it is part of their culture. African myth is used by okri to glorify his culture. Okri is equally good in using many genres at the same time. He devastatingly critiques meaningless and corrupt politics. History and politics are governed by the universal and repetitive cycle of greed. Okri's road passes through the ancient world of the spirits and is conceptualized with in traditional mythology.

In The Famished Road Okri gives Azaro a road that has an insatiable lust for liveslust in the sense of the word, as characterized by Madame Koto, and lust in the sense of a vampire medium, inherent in the predatory corruption of man against man. In $\underline{\text { Songs of }}$ Enchantment Azaro's father enters an enchanted kingdom and visualizes cowardice, powerlessness as the censoring forces which are preventing people to grow. He sings that people are unable to connect with the ecstasy of hidden heavens because of the innumerable piled up problems. He says that people should live their lives with true love and wise hope. In 
Infinite Richesthe governor general feels like an African himself and writes that the great jigsaw of humanity and human genius is distributed among all the people of the world. No one person or people have the possession of this jigsaw of humanity. Only together, as one people of this earth, facing our common predicament and redeeming love, we can fulfill our earthly journey.

The final destiny of man is to discover something of the great image or musicof our collective souls, of our immense possibilities, our infinite riches. Okri's spirit world is a world of ecstasy and joy. Spirits never experience pain and suffering. In the trilogy spirits take human forms to experience these things. They become vexed with their constant state. Sprits inform Azaro that humans make complete mess of ideals; they do terrible things to each other and turn the garden into grave yard. They prefer to live in their own ignorance.

A voice informs Azaro about centrality of love and asks him to raise and reach that immortal and precious inheritance. Spirits fail to take back Azaro because they forget that for the living, life is a story and for the dead, life is a dream. Azaro travels through $\underline{\text { The Famished }}$ $\underline{\text { Road }}$ of suffering and pain and enters an enchanted world in Songs of Enchantment and realizes that man's ultimate destiny is to find Infinite Riches which will help him in his Journey of life.

Okri's trilogy is presenting us the multidimensional nature of human life. The three headed spirit, symbolizing past, present, and future informs Azaro that getting worse and better is a continuous process. So, as long as life continues man has to struggle to achieve harmony. If man keeps his mind open and fills his life with love and compassion towards god's creation then he will realize his abilities which in turn help him lead a harmonious life. The manner, in which Okri passes on this message, makes him a phenomenon in world literature in general and African literature in particular. 


\section{Works Cited}

Aizenberg, Edna. "The Famished Road: Magical Realism and the Search for Social Equity", Comparative and General Literature 43(1995):25-30.

Cooper, Brenda. Magical Realism in West Africa. London: Routledge, 1998.

---.'Snapshots of Post-Colonial Masculinities. Alan Hollinghursts

$\underline{\text { The SwimmingPool Libraryand Ben Okri's The Famished Road."Journalof Common Wealth }}$ Literature.34.1 (1999): 135-157.

Hemminger, Bill. "The Way of the spirit": Research in African Literatures 32.1 (spring2001): $66-82$.

Mccabe Douglas. "Higher Realities"- New Age Spirituality in Ben Okri's TheFamished Road".

Okri, Ben. The Famished Road. London: Phoenix, 1991.

--- . Songs of Enchantment. London: Phoenix, 1993.

---.Infinite Riches. London: Phoenix, 1999.

---. Interview with Jane Wilkinson.

Talking with African Writers.Ed. Jane Wilkinson. London:Heinemann, 1992.

Singh, Satyanarayana. "Towards a New African Aesthetic, A Note on Myth and History in Achebe and Soyinka." Common Wealth Literature :ThemesandTechniques (1993):133-144.

Vazquez, Jose Santiago Fernandez. "Recharting the Geography of Genre: Ben Okri's The Famished Road as a Post Colonial Bildungsroman.” Journal of Common Wealth Literature 37.2(2002):85-107. 